\title{
Dysfunctional Policy Transfer in National Tax Blacklists
}

word count: 7285

\begin{abstract}
Common sense and much of the policy transfer literature suggests that learning from abroad delivers better policy at lower cost. In contrast, this article argues that policy transfer in tax blacklists has been a dysfunctional process tending to replicate errors. Rather than reflecting learning, normative mimicry or market pressures, over-committed policy makers have responded to complexity and crisis by unreflectively cutting and pasting from foreign models. Facing a short-term political imperative to "do something” about tax evasion in an environment of fiscal crisis, many policy makers have compiled blacklists of tax havens by copying lists of "the usual suspects” from abroad. Evidence for both the process of transfer and the dysfunctional nature of resulting policy is provided by tracking recurring errors in these lists that are unlikely to have arisen independently.
\end{abstract}

\section{KEYWORDS}

dysfunctional policy transfer, tax policy, blacklists, tax havens 
Policy-makers face a world of incredible complexity. Unlike scholars, not only must policymakers understand this complexity, they must also regulate or reform it, or at least some portion thereof. It is unsurprising, and perhaps even inevitable, that those charged with the responsibility to design policies seek to simplify in order to make problems comprehensible and tractable. One of the most prominent ways of doing so is to learn from abroad (Dolowitz and Marsh 2000). Rather than starting from scratch, governments can see how others have reacted to similar policy problems, sorting through foreign experience for successful and applicable examples to adopt at home. Such short-cuts are even more appealing in an atmosphere of crisis, where there is a political imperative for policy-makers to be seen to act, and act quickly.

If complexity is a general problem in policy formulation, the specific instance of tax policy represents an acute instance. National tax codes are notoriously long, complicated and incomprehensible, so much so that whole industries have arisen to help tax-payers navigate their way through the system (e.g. tax planners, tax law). Exacerbating this difficulty, increasing crossborder flows of trade and investment mean that those responsible for making and administering tax policy must consider the interaction of their own tax code with those of foreign jurisdictions. And there are more than 200 fiscally self-governing states and territories in existence, almost all with their own long, involved and often changing tax codes. Growing concerns about economic globalization have led to fears that governments' ability to maintain adequate tax revenue is becoming endangered. One common scenario posits the danger of a "race to the bottom" in taxes 
on mobile capital: because governments are in competition for scarce capital, which may increasingly relocate from high- to low-tax jurisdictions, governments are forced into a bidding war of successive tax cuts (Radaelli 1999). Tax havens, jurisdictions accused of seeking to attract foreign investment with a combination of low taxes, tight secrecy and lax regulation, are said to catalyze such a race to the bottom (OECD 1998; Webb 2004). The G20 heads of state summit in April 2009 was particularly exercised by the problem of regulating tax havens, bringing this issue to the forefront worldwide.

The combination of the complexity of tax, the centrality of tax for all state functions, and new concerns about tax haven-driven threats to government revenue have stimulated an energetic process of cross-border policy transfer. In an environment where the stakes are high and information is costly, governments have sought to protect their revenue and minimize the costs of gathering information by copying foreign policy solutions. In particular, many governments have sought to restrict citizens' and firms' ability to do business with, in or through tax havens by prescribing specific negative consequences for those transacting with such jurisdictions. Yet given the complex and rapidly changing nature of international tax rules, determining just which jurisdictions should be included as tax havens in such a blacklist is difficult, for either individual governments or collaborative efforts like the G20. This problem is all the more pronounced given the obscure geographical entities that can end up on such lists, from the Ostrava Free Zone to Qeshm Island. To circumvent this kind of problem, countries are prone to copy in a rather careless fashion from each other's lists. As a result, rather than well-researched lists based on in- 
depth comparative tax law and economic analysis, national tax authorities tend to paste together lists of “the usual suspects,” typically small islands.

The often arbitrary and inaccurate nature of such lists, discussed in the body of the article, gives an indication of how ineffective they can be. But beyond acting as a general indicator of effectiveness (or, in this case, ineffectiveness), the particular pattern and nature of certain mistakes also gives strong clues as to how policy transfer and emulation have occurred. Tracking the recurrence of mistakes from list to list provides indications of who is emulating whom, as well as how much thought they have put into the process of policy transfer. Such an exercise in tracking tell-tale errors helps to address the common difficulty of determining who is copying from whom, or whether in fact similar policy solutions have arisen independently of each other. This approach draws inspiration from Bennett:

Evidence of learning is not evidence of emulation, and the observation of the utilization of foreign experience is not proof of borrowing or copying. For... the emulation of policy content, the most careful and penetrating comparative policy studies have unearthed some quite staggering similarities even down to the wording of regulations.... [J]ust as plagiarism in student essays is exceedingly difficult to prove, so emulation can rarely be definitively established. Thus to conclude that convergence is attributable to emulation often requires some leaps in judgement... It is not something to which those doing the emulating will readily confess (Bennett 1991: 221). 
Through tracking mistakes in tax blacklists, the aim is to check for the presence and direction of just this kind of “policy plagiarism.”

The next section of the article reviews the relevant literature on policy transfer and cognate concepts (policy learning, policy convergence, etc.) to place the argument in context and formalize its contribution to the state of the debate. This is followed by a definition of national tax blacklists, and a brief summary of the various forms they may take. Evidence for dysfunctional policy transfer is drawn from an investigation of the errors that appear on various blacklists. Successively stronger claims are presented about the likelihood of unreflective "cut and paste” policy transfer. Initially the mistakes are relatively minor, and are only suggestive of copying. Later examples are serious mistakes that are very unlikely to have arisen independently. Finally, the last example is conclusive evidence of cutting and pasting. In copying the Mexican blacklist, Venezuelan officials forgot to replace references to "Mexico" with "Venezuela"; to make matters worse, because Mexico had blacklisted Venezuela, in copying the Mexican list word-for-word, Venezuela ended up blacklisting itself. The article also addresses two possible objections to the argument presented: that blacklists may be empty threats with no real impact, or that unreflective copying may be the least-bad alternative available to policy-makers.

The general conclusions are that in this context, policy transfer may actually perpetuate, rather than guard against, errors that render policies ineffective. Learning from abroad in the area of tax blacklists seems to be a false economy. Rather than reflecting rational learning or the search for normative legitimation, dysfunctional policy transfer in this instance represents a tempting way 
of cutting corners for over-committed policy makers facing the incredibly complicated policy environment of international taxation, and pressure to "do something” to stop international tax evasion. This pressure is felt all the more keenly in the context of the global economic crisis, with the near-catastrophic deterioration of many governments’ fiscal situation and the need to find plausible scapegoats to assuage popular anger. It would not be surprising if the same dynamics led to similar instances of dysfunctional policy transfer in other areas as well, though a much more ambitious study would be needed to confirm this suspicion.

\section{POLICY TRANSFER, LEARNING AND CONVERGENCE}

Those analyzing policy over the last few decades have been struck by the phenomenon of policies developed in one country being transferred or diffused to others. This process has been discussed under the rubric of a series of related and overlapping terms: policy transfer, policy learning, lesson-drawing, policy diffusion, policy convergence and others (for surveys of this literature see Bennett 1991; Dolowitz and Marsh 1996; Drezner 2001; special issue of Governance 2000; special issue of International Organization 2006; Holzinger and Knill 2005; Heichel et al. 2005; Meseguer and Gilardi 2009). Policy learning and lesson-drawing capture the notion of countries deliberately drawing on foreign examples. To some extent, this rendering is a good fit with the dynamic at work in tax blacklists, which involves voluntary engagement with practices in other countries. However because "learning" and "lesson-drawing" tend to connote a progressive move from ignorance to knowledge and less efficient to more efficient solutions, the more neutral term of policy transfer is generally preferred. Policy transfer may lead to better 
policy than the status quo, as is widely appreciated, but also a worse policy, a much less intuitive point. Policy transfer is defined as occurring when "knowledge about policies, administrative arrangements, institutions and ideas in one political setting (past or present) is used in the development of policies, administrative arrangements, institutions and ideas in another political setting” (Dolowitz and Marsh 2000: 5). Aside from relying on their definition, this article also adopts the continua for analyzing policy transfer suggested by Dolowitz and Marsh. These are the degree to which policy transfer is voluntary or coercive, the extent to which foreign models are directly copied or merely suggestive, and the degree to which the policies transferred are effective in their new environments.

The national tax blacklists in question were transferred voluntarily, rather than being imposed by powerful outside states or international organizations. Most blacklist transfers have been copied but in most cases have also retained national variation. Although effectiveness is difficult to judge in terms of the impact on tax collection, the presence of careless mistakes in the lists provides strong circumstantial evidence of their ineffectiveness. A fortiori, if those adopting the list have fundamental problems with basic geographical issues, they are unlikely to be productively capturing the much more complex and volatile world of international tax practices. The built-in obsolescence of the lists, indicated by the use of terms that are decades out of date, again suggests they do little to protect the fisc. As is discussed below, in some cases lists are adopted after their originators have disowned or distanced themselves from their compilations. Furthermore, there is some evidence that measures designed to protect a country's revenue actually retard that country's export potential. A definitive assessment of effectiveness would 
depend upon a calculation of the amount of extra tax collected that would have been forgone, but for the presence of blacklists. No one has such figures, least of all the national tax authorities in question.

For scholars studying diffusion (e.g. Meseguer and Gilardi 2009), and sociologists investigating the spread of innovation and "institutional isomorphism” (Strang and Soule 1998), the channels through which practices and institutions are diffused are a key concern. If tax blacklists have been copied from one country to the next, what are the links through which this process occurred? Tax administrators are enmeshed in a transnational epistemic community (Haas 1992; Stone 2004). Within this community the OECD Committee on Fiscal Affairs is a central hub. Through its seminars the OECD brings together national officials, and it diffuses best practice through its publications, within but also beyond the OECD member states (Porter and Webb 2004). For example, the OECD’s Global Forum on Tax in November 2005 was attended by officials from 81 countries. The OECD Secretariat conducts regional outreach conferences in Latin America and Asia as well as Europe and North America.

The United Nations has its own Committee of Experts on International Tax Co-operation, as does the Commonwealth (Commonwealth Association of Tax Assessors). At the regional level are bodies like the Inter-American Center of Tax Administrations (CIAT) and the Pacific Association of Tax Assessors. Like the OECD, rather than acting as discrete self-contained institutions, these bodies facilitate the creation of networks of national tax officials, networks through which policy ideas can be exchanged and emulated (Slaughter 2004). Perusing the titles 
of conferences and workshops hosted by these organizations reveals that national tax officials do indeed present papers explaining how their respective blacklists work to their foreign counterparts. This knowledge is further disseminated in specialist tax journals like Tax Notes International, Offshore Investment, Intertax, Journal of International Taxation, etc. While the process of intellectual exchange within these networks may lead to the diffusion of successful tax policy innovations (for example Value Added Tax models, Bird and Gendron 2007), it can also be the channel for inappropriate copying of faulty models.

Despite the proliferation of terms for the similar and overlapping processes of transfer and diffusion, there is broad agreement on the mechanisms involved (Meseguer and Gilardi 2009; Weyland 2005). The first of these, policy learning, is based on the common sense or rationalist position of adapting successful foreign models for use at home. Sharing experience and accumulating knowledge on different policy practices produces better outcomes for lower costs than intellectual autarky among policy-makers. Lenschow et al. capture the logic of policy learning:

[Countries] largely face that same types of problems, ranging from the organization of the fire brigade to environmental deterioration. These countries, moreover, maintain increasingly intensive relations, for instance through trade, tourism, media, or international co-operation. This would make it plausible that policy-makers learn from each other and, on the longer term, reach some kind of implicit or even explicit agreement on which policies are considered "optimal” and ought to be followed (2005: 797-98). 
Even in the absence of perfect rationality, borrowing on the basis of bounded rationality or cognitive heuristics may underpin considerable transfer and convergence (Weyland 2005).

Sociologists, however, are keen to emphasize the search for normative acceptance and legitimacy rather than technical efficiency as an alternative mechanism explaining the tendency of institutions and practices to diffuse across borders (Finnemore 1996; Meyer et al. 1997; Strang and Soule 1998). Here, for example, policies are adopted to signal adherence to the model of the progressive, advanced, modern state, rather than to solve particular local problems. Policy norms become established once dominant states have led the way, or a certain tipping point has been reached. More recently international organizations act to homogenize national policy by promoting and valorizing particular models (Barnett and Finnemore 2004). Recent International Relations literature has posited the impact of coercion or competition mechanisms in explaining policy similarities across disparate national contexts (Drezner 2001; International Organization 2006). Powerful states and international organizations may insist on neo-liberal economic reforms as a condition for disbursing cheap credit or aid. Or the competition for globally mobile capital may lead countries to adopt similar, market-friendly policy in order to attract investment, analogous to the "race to the bottom" scenario noted earlier. But there is reason to believe that none of these mechanisms fully captures the motivations behind the adoption of national tax blacklists. As the sections below seek to illustrate, such lists have been adopted voluntarily but unreflectively. They would seem to confer little advantage in either attracting capital or establishing membership credentials in the community of advanced, progressive, modern states. 
Before substantiating these assertions, however, it is necessary to sketch out what national blacklists are, and how they work.

\section{WHAT ARE NATIONAL TAX BLACKLISTS?}

Countries take a variety of approaches to guarding their national tax revenues. National tax blacklists are a common method by which governments try to limit tax losses at home by limiting or barring transactions carried out by their citizens or corporations with certain specified foreign jurisdictions. For the purposes of this article, national tax blacklists are defined as legislation or regulations that prescribe negative treatment for certain transactions that involve specific listed foreign jurisdictions. Such blacklists are national in the sense that they are formulated and enforced by public authorities, rather than private firms. The reference to tax blacklists is shorthand for lists of jurisdictions that may exist in many different aspects of countries' tax codes and related laws and regulations. Finally, they are blacklists in that the specified consequences are negative: punitive taxes, more burdensome reporting requirements, and so on. To count as a blacklist, the legislation or regulations must be based on or refer to lists of jurisdictions, rather than abstract objective criteria. So, for example, if a particular regulation specified negative treatment for transactions involving any and all jurisdictions with a corporate tax rate of less than 25 percent, but made no reference to a list of particular jurisdictions (as in Japan), this would not count as a blacklist for our purposes. A rough rule of thumb is: no proper nouns, no national tax blacklist. 
Tax havens are said to pose a risk to government revenue in several ways. Firstly, by providing offshore bank accounts, companies and trusts in tax havens may obscure financial information necessary to ensure that tax payers meet their obligations in full (Palan 2003). To the extent that governments cannot see and measure their citizens' assets and income, they cannot tax them. In this respect, the G20 countries have made their intentions clear: "National and regional authorities should implement national and international measures that protect the global financial system from unco-operative and non-transparent jurisdictions that pose risks of illicit financial activity... Lack of transparency and a failure to exchange tax information should be vigorously addressed” (http://www.g20.org/Documents/g20_summit_declaration.pdf).

Secondly, tax havens may provide a legal fiction: business that really takes place in a high-tax jurisdiction can be booked in a low-tax jurisdiction, such as through transfer pricing (Picciotto 1999). In this manner, by manipulating the pricing of inputs from different national divisions, multinational firms can book their profits in tax havens and engineer tax-deductible losses at home. Thirdly, tax havens with access to tax treaty networks can be used as conduits to minimize the tax a firm pays on its foreign operations. For example, Canadian firms that route their foreign profits through a Barbadian holding company pay only 2.5 percent tax, instead of the 21 percent that would usually apply. Foreign investors in India are best served by using Mauritius as a conduit to escape tax on repatriated profits.

What are the specific provisions of such national tax blacklists? Most national blacklists fall into one of four types: Controlled Foreign Company, Transfer Pricing, Disallowance of Deductions 
and Withholding Tax. Controlled Foreign Company (CFC) legislation was first created in the US in the 1930s, and much later diffused through the OECD countries. It was designed to address the problem whereby citizens could avoid personal income tax at home by attributing this income to a foreign company entirely under their control incorporated in a low- or no-tax jurisdiction. Under CFC blacklists the domestic shareholders of companies incorporated in listed jurisdictions are taxed as if all profits from these companies had been distributed to the shareholders, even if the profit has remained abroad.

Transfer pricing refers to the practice whereby multinational firms must allocate their overall profit to particular national divisions by putting a price on intra-company trade. The governing principle that should apply is the arm's length trade: intra-firm trades should be priced at the same price as would apply if unrelated entities were executing the same trade. But because these intra-firm prices are a fiction, in that different parts of the same company do not actually buy and sell from each other, there is room for manipulation to book profits in low-tax countries and losses in high-tax countries. Transfer pricing blacklists mean that trading between associated entities involving blacklisted jurisdictions is automatically regarded as in violation of the arm's length principle, and thus punitive tax rates are applied. Disallowance of deductions lists mandate that tax deductions that would normally be allowed for individuals and companies are disallowed for transactions within or involving listed jurisdictions. The burden of proof is reversed: instead of the presumption that tax-payers have incurred a legitimate business expense, it is presumed that tax-payers have not incurred a legitimate business expense unless they can convince the tax authorities otherwise. Finally, under withholding tax blacklists, withholding 
taxes are automatically applied to transactions with listed jurisdictions, and the onus is on taxpayers to demonstrate why some or all of this tax should be reimbursed. Like CFC and Transfer Pricing legislation, generalized withholding taxes may be applied, but these don't count as a tax blacklist unless there is an associated list of "deviant” jurisdictions. To repeat, the rule is no proper nouns, no blacklist (see the examples below).

\section{***TABLE 1 ABOUT HERE***}

Compiling a tax blacklist requires tax authorities to sort the world into "normal” and "deviant," tax haven jurisdictions, with the latter to be featured on the list. While at first blush this may seem relatively simple, in practice it is a difficult task. Headline tax rates for personal or corporate income tax may convey little evidence on how much tax individuals and firms are actually liable to pay. For example, firms may actually pay less tax in a country with a high corporate tax rate but generous depreciation allowance, compared with another country that has a lower headline corporate tax rate but no depreciation allowance. It is common for tax havens to have a relatively "normal” tax structure and substantial headline rates, but to allow very favorable effective rates and exemptions for foreign investors (Doggart 2002).

The procedures that tax authorities use for drawing up national tax blacklists are surprisingly opaque. Some countries like France simply do not have any formal procedure for drawing up such lists, or any rationale that explains why some jurisdictions are listed whereas others are not (Tax Code Article 238A 1975). Often, rather confusingly, countries like Venezuela do specify a 
formal methodology in their legislation or regulation, but then do not actually use it in drawing up their lists. Then again, countries may have a formal methodology or rule for generating blacklists that was faithfully applied when the list was first created, but has since become out of date, like Argentina (Section 124 Company Act 2003). Tax laws and tax rates are constantly changing. So unless there is a major commitment of time and resources to keeping such lists current by regularly re-evaluating scores of jurisdictions, lists quickly become obsolete and inaccurate.

Although national tax blacklists are common, they are by no means universal. And although some countries have recently moved towards adopting such a list in countering international tax evasion (e.g. South Korea in October 2006, India in November 2006), others have de-emphasized their list (e.g. Mexico from January 2005), or abolished such lists altogether (e.g. Australia and Japan in the early 1990s). A selection of the countries employing national tax blacklists includes Argentina, Belgium, Brazil, Colombia, France, Greece, Hungary, India, Italy, Kazakhstan, Lithuania, Mexico, Peru, Poland, Portugal, South Korea, Spain, Ukraine and Venezuela (Author 2005, Langer 2003, OECD 2004).

\section{TRACKING TRANSFERS THROUGH ERRORS}

This article claims that national tax blacklists have been transferred internationally, and have tended to lead to dysfunctional policy outcomes. Generally the transfer has been state-to-state, but there are some examples of countries copying from international organizations. This section 
adduces evidence both for the often inaccurate nature of these lists, and the tendency to be copied by looking at a series of errors contained in these lists. While the initial errors examined may well have arisen independently, it is very difficult to see how those discussed later could have come from anything but cut-and-paste policy transfer.

Even a cursory examination of national tax blacklists reveals idiosyncratic errors that do not inspire much confidence regarding their accuracy. Colonial-era names of jurisdictions are left unchanged for decades after independence. The Spanish list of 1991 included "the Windward Islands," even though as a political and fiscal unit this had been dissolved since 1960. The French list continues to include the Gilbert and Ellice Islands, even though in 1978-79 this territory achieved independence as two separate countries (Tuvalu and Kiribati). The Ukrainian list included "Damask" which does not seem to exist as a geographical or fiscal unit at all (Langer 2003). But although they may indicate a certain sloppiness in drawing up the lists, these errors do not provide any evidence of transfer between countries.

More suggestive of transfer are the common errors contained in the lists of Argentina, Mexico, Portugal and Venezuela (Argentina in Decree 1037/2000 of 14 November 2000, Law No. 25,239, Law 25,784, Law 25,795; Mexico’s List of Territories with Preferential Tax Regimes, subparagraph VI Articulo Transitoro Unico of Income Tax Law 1996, modified by Articles 212215 Income Tax Law 2005; Portugal’s Reforma do Patrimonio of 30 July 2003 and Potaria No.150/2004 of 13 February 2004; and Venezuela’s Resolution SENIAT of 19 March 2001, modified 15 January 2003). Given the timing, it seems that the 1996 Mexican list was copied by 
the other three countries. Mexico itself has since 2005 largely abandoned the use of its tax blacklist as ineffective, but this has not dampened the enthusiasm of its imitators.

In addition to naming several Pacific island countries, the blacklists of Mexico, Argentina, Portugal and Venezuela contain the entry "Pacific islands," without further detailing which jurisdictions are to be included. The problem with a general "Pacific islands" entry is that it does not refer to a juridical or fiscal entity. Instead it is a general geographical term that includes a huge variety of countries, territories and, most importantly, tax regimes. Hawai'i, Fiji, French Polynesia and Japan are Pacific islands, but they have very little in common in terms of their tax codes. Because the Pacific islands are not a legal or fiscal entity, including them on a blacklist makes about as much sense as an entry for "Western Europe" or "the third world."

The second kind of error is in including islands that have no separate tax code. That is to say, despite the geographical separation, there is no fiscal separation from the countries of which they are part. In the Indian Ocean, the Australian territories of Christmas Island and Cocos (Keeling) Islands are included on the Argentine, Mexican, Portuguese and Venezuelan lists. The Cocos (Keeling) Islands were largely independent until 1978, when Australia forcibly purchased the islands from its ruling family. Currently neither Australian territory (which have only the most rudimentary banking facilities) enjoys any special exceptions relating to corporate law, nor corporate income tax rates, nor tax information exchange (Personal communication, Australian Department of Transport and Regional Services). Because there is no fiscal separation it makes no sense to blacklist these islands without blacklisting Australia as a whole. 
A similar problem applies in the Atlantic Ocean with reference to the tiny British island territories of St Helena, Ascension Island and Tristan da Cunha, which again appear on the Mexican, Argentine, Portuguese and Venezuelan blacklists. These islands jurisdictions make unlikely centres of international finance. Previous to April 2004 none of these islands had a single bank. Before the 1960s the eight families on Tristan da Cuhna did not use money. St Helena has a corporate tax rate of 30 percent. When the Mexican list, which again seems to have been the basis for the Argentine, Portuguese and Venezuelan lists, was compiled in 1996 both islands' financial and company law was simply that of the UK, although this has changed since April 2001 (Personal communication with the administrators of Ascension Island, St Helena and Tristan da Cunha). The lack of legal separation between the islands and the UK proper for banking and financial purposes again means it does not make sense to list these two territories while excluding the UK itself.

From 1996 the Mexican list has included the entity "Patau.” There is no such territory or country as "Patau," the closest being Palau, a Pacific island state that obtained independence in 1994 after being a United States-administered United Nations trust territory. In its 2003 list Argentina also had an entry "Patau," strongly suggesting that Argentina had simply copied the same mythical island from Mexico.

The "smoking gun" of dysfunctional policy transfer in relation to national tax blacklists is provided by Venezuela. In his study of pension reforms in Latin America, Kurt Weyland notes 
that: “The original Colombian reform proposal, for example, was so close to the Chilean model that one World Bank adviser joked that they had taken the Chilean legislation and used a search and replace function to substitute the world 'Chile' with 'Colombia'” (2005: 292). When Venezuelan tax officials copied the Mexican blacklist, however, they forgot even this minimal adaptation. Instead the Venezuelan legislation made reference to the wishes of the Mexican legislature and the need to be consistent with the Mexican constitution. Worse still, the original Mexican list had included Venezuela, and thus by copying the Mexican list, Venezuela succeeded in blacklisting itself (Langer 2003: 4).

Aside from these examples of state-to-state transfer, tax authorities have also sought to emulate the lists produced by international organizations. In 2000 the OECD came up with a list of tax havens (Sharman 2006), while between 2000 and 2006 the Financial Action Task Force maintained a list of jurisdictions deemed to be non-co-operative in the fight against money laundering (the Non-Co-operative Countries and Territories [NCCT] list) (FATF 2000). Once again, transfer has tended to produce problematic results. The danger of using multilateral lists to construct national lists is that the latter tend to be static and unresponsive to changing circumstances, especially when codified in legislation. This danger is evident in the way that lists produced by the OECD and the Financial Action Task Force (FATF) have been adopted by countries since their release in 2000. For example, with Resolution 7 of 2003, amending section 124 of the Argentine Companies Act, Argentina adopted the FATF's list of Non-Cooperative Countries and Territories without considering that this listing is subject to continual revision and updating. Argentina added seven listed NCCTs to its tax blacklist. Since that resolution was 
passed, however, the number of NCCTs has been reduced to zero, but Argentine legislation does not reflect this change.

Both the United States and Colombian government have sought to directly incorporate the OECD's list of tax havens in their national tax blacklists. The Colombian government attempted to directly copy the OECD to form its national tax blacklist in 2005. This transfer was vetoed, however, by the Supreme Court which argued that such a direct transfer from outside was unconstitutional (Personal Communication Panamanian Ministry of Finance). The United States Senate has been the site of many attempts to confront tax haven-assisted tax evasion, attempts that at least until 2007 have usually been defeated in the House of Representatives. Thus for example in 2005 legislation (S 779) to amend the 1986 Internal Revenue Service Code would have imposed punitive Controlled Foreign Company regulations on companies based in tax havens, with the list of tax havens taken directly from the OECD’s 2000 list.

Although the OECD list was not as fluid as the money laundering based NCCT list, directly incorporating it into national legislation raises similar issues. When the list was first compiled the OECD took pains to note that this was not intended to be used as the basis for punitive measures (OECD 2000: 17). Also in 2005 in response to the tendency to copy its list the OECD Global Forum on Tax was moved to note its concern:

If a country chooses to use a list derived from the OECD list, it should do so on the relevant current facts. Thus, progress made in the implementation of the principles of transparency and effective exchange of information in tax matters 
should be taken into account by such countries and their legislatures... More than five years have passed since the publication of the OECD list and positive changes have occurred in individual countries' transparency and exchange of information laws and practices since that time (OECD 2005: 8).

There is so far little indication that countries have taken this caution to heart in compiling their tax blacklists.

Before concluding, there are two further possibilities that must be examined. First, it might be thought that the long-term persistence of the kind of glaring errors covered above could indicate that these blacklists are a dead letter, announced for public effect, but not implemented, and hence without economic consequence to either the issuing or target jurisdictions. But the fragmentary evidence on offer tells a different story. Those from both the public and private sector in those countries on the receiving end of such measures indicate that the lists create real impediments to business. In a sign of the unintended consequences of the lists, the effects are sometimes most likely hinder the international trade of the imposing country. For example, a Brazilian company bought an interest in the airport in Curaçao, Netherlands Antilles, only to have to lobby for exemption from its government's penalties for dealings with tax havens (Author’s interview, Curaçao International Finance Association, 23 February 2009). Similarly, many European engineering companies interested in bidding for work on the expansion of the Panama Canal had to negotiate exemptions or suffer the penalties of transacting with Panama (Author’s interview, Panamanian Ministry of Finance, 3 April 2008). A Chilean mining firm looking to buy equipment from Barbados had to go to the trouble and extra expense of setting up 
an intermediary to process the transaction (Author's interview, Barbadian Ministry of Industry and International Business, 29 June 2005). In each case the blacklists acted to restrict or impinge upon legitimate trade and investment beneficial to all parties involved, where tax concerns were largely irrelevant. And the belief among blacklisted countries is that for every company that labors to find a way around such restrictions or shoulders the extra costs involved in order to engage in non-tax-driven trade and investment, there are many others that simply steer clear.

The second possible objection to the argument put forward so far is that copying blacklists, though prone to error, may be the least-bad alternative available to the countries in question. Conducting a census of tax havens from scratch is expensive, and may also include some misclassifications. Might the costs of policy originality be greater than those associated with copying faulty models from abroad? Such a trade-off rests on a false dichotomy: it is not that countries have to have tax blacklists, and the choice is only whether they are home-grown or aped from others. Many developing and developed countries have no list at all, and as remarked upon previously countries like Japan and Australia that previously did employ this device have since abandoned it. Even if countries did feel the need to penalize particular kinds of transactions with certain jurisdictions, this could be done in a tailored and ad hoc fashion. For example, some of the proposed instances of US legislation against tax havens would provide the Secretary of the Treasury with the authority to nominate and remove jurisdictions for unfavorable tax treatment as circumstances dictated (modifying the framework of the Patriot Act section 311). Such a measure could quickly respond to international tax problems as they arose, without the built-in obsolescence and inflexibility that a legislated list entails. Given these alternatives, it is difficult 
to see any fiscal rationale that justifies the draw-backs of dysfunctional policy transfer in this domain, despite the current emphasis the G20 has put on such blacklists. Copying from abroad in this instance is a false economy.

\section{CONCLUSIONS}

Common sense as well as much of the literature on policy learning and policy transfer would suggest that the process of emulation leads to better policy outcomes at a lower cost. Rather than re-inventing the wheel every time, policy makers can learn from the successes and failures of others to craft better policy. This tendency to emulation would seem to make all the more sense in very complex areas like taxation, and specifically the compilation of national tax blacklists. But in tax blacklists at least, those emulating foreign models have copied existing mistakes, and then often added some of their own. Even when the original lists have been initially accurate, by the time they have been copied the passage of time has rendered them obsolete and inaccurate. Rather than simple bounded rationality under which policy-makers accept "good enough" solutions instead looking for perfection (satisfycing rather than optimizing), the result has been dysfunctional policy transfer. Tax authorities have blacklisted jurisdictions with no financial sector, or no separate fiscal existence, or that no longer exist, or that have never existed. In the extreme instance, policy-makers in Venezuela were so careless as to blacklist their own country. While the authorities in question have not collected data that allow a definitive conclusion on the effect of these lists, these gross errors strongly suggest that these lists are nowhere near adaptive or flexible enough to capture the play of constant changes in tax laws and international business 
practices. Further confirming evidence of ineffectiveness is the tendency to copy lists against the advice of their creators (e.g. OECD and the FATF), or after they have been found wanting by their originators (e.g. Mexico). Because of the difficulty of distinguishing emulation from independent paths to the same result, this article has adopted the strategy of tracking repeated mistakes. Like student plagiarism, particular mistakes replicated (like blacklisting imaginary jurisdictions) across cases are indicative of unreflective cutting and pasting.

Literature on policy diffusion and institutional isomorphism indicates that dysfunctional transfers are common, but would posit different reasons as to why these might come about. Factors behind dysfunctional transfer might include coercion from the World Bank or IMF, or the privileging of normative acceptance and legitimacy over technically efficient policy outcomes. Yet the tax blacklists are voluntary, and are not a taken-for-granted international norm, so these mechanisms do not seem to have been in play. Many important countries do not have such a list (e.g. Britain, Japan, Canada, China), and influential international organizations like the OECD have argued against their use (OECD 2005). Instead policy makers seem to have succumbed to the "do something" reflex in response to tax evasion, and then have taken the line of least resistance (copying) in carrying out this reflex. The pressures that give rise to such short-cuts are especially acute in an environment of economic crisis and popular discontent. Although it would require a much broader study than this one to substantiate, it seems likely that the same environment may have given rise to similarly dysfunctional results in transferring other kinds of policies. 
Tax authorities adopting blacklists in response to fears of tax-haven provoked revenue loss are thus in an analogous situation to police rounding up "the usual suspects" after a crime. The actual process of investigating the crime to find the real perpetrators is usually difficult, timeconsuming and expensive. Yet doing nothing in response leaves the authorities vulnerable to a backlash from the public. Singling out the usual suspects satisfies the public relations imperative to do something, while sparing the expense of a genuine investigation. When applied to national tax blacklists, the chances of a move premised on this logic actually generating any extra tax revenue seem very small indeed. 


\section{BIBLIOGRAPHY}

Barnett, M. and Finnemore, M. 2004. Rules for the World: International Organizations in Global Politics, Ithaca: Cornell University Press.

Bennett, C. 1991. 'Review Article: What is Policy Convergence and What Causes It?' British Journal of Political Science 21: 215-33.

Bird, R.M. and Gendron, P-P. 2007. The VAT in Developing and Transitional Countries, Cambridge: Cambridge University Press.

Doggart, C. 2002. Tax Havens and their Uses, London: Economist Intelligence Unit.

Dolowitz, D. and Marsh D. 1996. 'Who Learns What from Whom: A Review of the Policy Transfer Literature’, Political Studies 44: 343-51.

Dolowitz, D. and Marsh, D. 2000. 'Learning from Abroad: The Role of Policy Transfer in Contemporary Policy-Making', Governance 13: 5-24.

Drezner, D. 2001. 'Globalization and Policy Convergence’, International Studies Review 3: 5378. 
FATF. 2000. Report on Non-Co-operative Countries and Territories, Paris.

Finnemore, M. 1996. ‘Norms Culture and World Politics: Insight from Sociology’s Institutionalism’, International Organization 50: 325-47.

Haas, P. 1992. 'Introduction: Epistemic Communities and International Policy Co-ordination’, International Organization 46:1-35.

Heichel, S., Pape, J. and Sommer, T. 2005. 'Is there Convergence in Convergence Research? An Overview of Empirical Studies on Policy Convergence', Journal of European Public Policy 12: 817-840.

Holzinger, K. and Knill, C. 2005. 'Causes and Conditions of Policy Convergence’, Journal of European Public Policy, 12: 775-96.

Langer, M. 2003. 'Blacklists', Paper presented at the International Tax Planning Association conference, Cannes.

Lenschow, A., Liefferink, D. and Veenman, S. 2005, 'When the Birds Sing. A Framework for Analysing Domestic Factors Behind Policy Convergence', Journal of European Public Policy 12: 797-816. 
Meseguer, C. and Gilardi, F. 'What is New in the Study of Policy Diffusion', Review of International Political Economy 16: 527-543.

Meyer, J., Boli, J., Thomas, G., and Ramirez, F. 1997. 'World-Society and the Nation-State’, American Journal of Sociology 103: 144-66.

OECD. 1998. Harmful Tax Competition: An Emerging Global Issue, Paris.

OECD. 2000. Towards Global Tax Co-operation, Paris.

OECD. 2004. Subgroup on Level Playing Field Issues: Proposals for Achieving a Global Level Playing Field, Paris.

OECD. 2005. Progress towards Achieving a Level Playing Field: Outcomes of the OECD Global Forum on Taxation, Paris.

Palan, R. 2003. The Offshore World: Sovereign Markets, Virtual Places, and Nomad Millionaires, Ithaca: Cornell University Press.

Picciotto, S. 1999. 'Offshore: The State as Legal Fiction', in Offshore Finance Centres and Tax Havens, edited by M. Hampton and J. Abbott, 43-79. West Lafayette: Ichor. 
Porter, T. and Webb, M. 2004. 'The Role of the OECD in the Orchestration of Global Knowledge Networks', paper presented at the International Studies Association meeting, Montreal.

Radaelli, C. 1999. 'Harmful Tax Competition in the EU: Policy Narratives and Advocacy Coalitions', Journal of Common Market Studies 37: 661-82.

Sharman, J. 2006. Havens in a Storm: The Struggle for Global Tax Regulation, Ithaca: Cornell University Press.

Slaughter, A. 2004. A New World Order, Princeton: Princeton University Press.

Stone, D., 2004 'Transfer Agents and Global Networks in the “Transnationalization” of Policy’, Journal of European Public Policy 11: 545-66.

Strang, D. and Soule, S. 1998. 'Diffusion in Organizations and Social Movements: From Hybrid Corn to Poison Pills’, American Review of Sociology 24: 265-90.

Webb, M. 2004. 'Defining the Boundaries of Legitimate State Practice: Norms, Transnational Actors, and the OECD’s Project on Harmful Tax Competition', Review of International Political Economy 11: 787-827. 
Weyland, K. 2005. 'Theories of Policy Diffusion: Lessons from Latin American Pension Reform’, World Politics 57: 262-95. 
Dysfunctional Policy Transfer in National Tax Blacklists

TABLE 1: SAMPLE BLACKLISTS: BRAZIL AND SPAIN

Brazil’s Transfer Pricing Blacklist ${ }^{1}$

\begin{tabular}{|c|c|c|c|c|}
\hline Andorra & Anguilla & $\begin{array}{l}\text { Antigua } \quad \text { and } \\
\text { Barbuda }\end{array}$ & $\begin{array}{l}\text { Netherlands } \\
\text { Antilles }\end{array}$ & Aruba \\
\hline Bahamas & Bahrain & Barbados & Belize & Bermuda \\
\hline Campiogne d'Italia & $\begin{array}{ll}\text { Channel } & \text { Islands } \\
\text { (Alderney, } & \\
\text { Guernsey, } & \text { Jersey } \\
\text { and Sark) } & \end{array}$ & Cayman Islands & Cyprus & Singapore \\
\hline Cook Islands & Costa Rica & Djibouti & Dominica & $\begin{array}{l}\text { United } \\
\text { Emirates }\end{array}$ \\
\hline Gibraltar & Grenada & Hong Kong & Labuan & Lebanon \\
\hline Liberia & Liechtenstein & Luxembourg & Macau & Madeira \\
\hline Maldives & Malta & Isle of Man & Marshall Islands & Mauritius \\
\hline Monaco & Montserrat & Nauru & Niue & Oman \\
\hline Panama & St Kitts and Nevis & American Samoa & Western Samoa & San Marino \\
\hline $\begin{array}{l}\text { St Vincent and the } \\
\text { Grenadines }\end{array}$ & St Lucia & Seychelles & Tonga & Turks and Caicos \\
\hline Vanuatu & $\begin{array}{l}\text { Virgin } \\
\text { British }\end{array}$ & Virgin Islands, US & & \\
\hline
\end{tabular}

Spain’s Controlled Foreign Company Blacklist ${ }^{2}$

\begin{tabular}{|c|c|c|c|c|}
\hline Andorra & Anguilla & $\begin{array}{l}\text { Antigua and } \\
\text { Barbuda }\end{array}$ & Aruba & Bahamas \\
\hline Bahrain & Barbados & Bermuda & British Virgin Islands & Brunei \\
\hline $\begin{array}{l}\text { Cayman } \\
\text { Islands }\end{array}$ & Cook Islands & Cyprus & Dominica & Falklands \\
\hline Fiji & Gibraltar & Grenada & Guernsey/Sark/Alderney & Hong Kong \\
\hline Isle of Man & Jamaica & Jersey & Jordan & Lebanon \\
\hline Liberia & Liechtenstein & $\begin{array}{l}\text { Luxembourg } \\
\text { (1929 Holding } \\
\text { Companies) }\end{array}$ & Масао & Malta \\
\hline Mauritius & Monaco & Montserrat & Nauru & $\begin{array}{l}\text { Netherlands } \\
\text { Antilles }\end{array}$ \\
\hline $\begin{array}{l}\text { Northern } \\
\text { Marianas }\end{array}$ & Oman & Panama & San Marino & Seychelles \\
\hline Singapore & Solomon Islands & St Lucia & $\begin{array}{l}\text { St Vincent and the } \\
\text { Grenadines }\end{array}$ & $\begin{array}{l}\text { Trinidad } \\
\text { Tobago }\end{array}$ \\
\hline $\begin{array}{l}\text { Turks and } \\
\text { Caicos }\end{array}$ & $\begin{array}{l}\text { United } \\
\text { Emirates }\end{array}$ & $\begin{array}{l}\text { US } \\
\text { Islands }\end{array}$ & Vanuatu & \\
\hline
\end{tabular}

${ }^{1}$ Source: Normative Instruction 188/02 of 6 August 2002

${ }^{2}$ Source: Royal Decree 1080/1991 of 5 July 1991 as modified by Royal Decree 116/2003 of 31 January 2003. 